\title{
How Carbon Emission Quotas Can be Allocated Fairly and Efficiently among Different Industrial Sectors: The Case of Chinese Industry
}

\author{
Feng Dong*, Yu Han, Yuanju Dai, Ruyin Long**, Bolin Yu \\ School of Management, China University of Mining and Technology, Xuzhou, China
}

Received: 11 October 2017

Accepted: 14 December 2017

\begin{abstract}
Emissions trading schemes (ETS) have been treated as a cost-effective mitigation measure to effectively control carbon emissions. Industrial carbon emission quota allocation is prior to the implementation of ETS. This study takes industrial sectors in China as a case to apportion carbon emission quotas. An informational entropy and multiple-factor mixed weighting allocation model (IEMMA) was established by considering fairness, efficiency, and feasibility from 4 aspects, i.e., emission reduction responsibility, emission reduction potential, emission reduction capacity, and industrial features. The allocation results among industrial sectors present many differences, and averaging a weighting allocation scheme is more feasible than other allocation schemes considering the fairness, efficiency, and feasibility. This study not only advances the existing literature on the issue of sectoral carbon emission quota allocation, but also provides a significant reference for China's policymaking in ETS implementation.
\end{abstract}

Keywords: China, industrial sectors, carbon emission quota allocation, IEMMA, ELC

\section{Introduction}

Melting glaciers, rising sea levels, weather anomalies and environmental disasters are the consequences of global warming which degrades the environment, the economy and infrastructure [1]. Countries worldwide have all realized that global warming brings a huge challenge to human existence and development. As a big responsible country, China has acted in an active and responsible way in global emission reduction. Up to now, China has made a lot of commitments, for instance, China pledged to reduce its carbon emissions per unit of GDP

*e-mail: dongfeng2008@126.com

**e-mail: longruyin@163.com (also called carbon emission intensity, CEI) by $40-45 \%$ and $60-65 \%$ compared to 2005 levels by 2020 and 2030 [2], respectively. To achieve the above emission reduction commitments, China has launched its carbon emissions trading pilots in seven provinces and municipalities in 2013 and 2014, further to establish a pilot nationwide carbon trading market by 2017 and then construct a unified emissions trading market by 2020 [3].

A wealth of literature has raised the discussion about how to allocate carbon emission quotas. The principles of carbon emission quota allocation mainly include the following categories. The first category is based on the traditional allocation principles, mainly grandfather principle and fairness principle. Grandfather principle is a gratis allocation principle, and mostly is applied at the beginning stage of a carbon emissions trading scheme. 
In the process of carbon emissions quota allocation, equality, equity, and exemption are the 3 different but complementary notions of distributive fairness [4]. The second category is built on the efficiency principle, which is mainly related to the economic efficiency of emissions reduction. Some scholars consider the carbon emission allowance allocation among different regions [5-6]. The third category allocates carbon emission quotas based on both fairness and efficiency principles [7-8].

Corresponding to the above principles, many different allocation methods have been proposed. Shapley's value method [9-10] and the DEA model [11-12] are the most widely used in carbon emissions allocation. In addition, the decomposition method is always used to analyze carbon emissions further and direct how to allocate carbon emission quotas [13-14]. Recently, some scholars construct the comprehensive and complex allocation models to investigate emission quota allocation, such as assumed weight sum model [15], nonlinear programming model [16], and fuzzy clustering analysis [17].

The initial allowance allocation mechanism is crucial for controlling the total emission level and ensuring the operational efficiency of the trade mechanism [18]. Besides, it plays a fundamental role in allocating carbon emissions among industries and apportioning carbon emissions into each industrial sector in the development of the national carbon emissions trading market. As the industrial sectors possess the highest energy consumption and the most rapid growth in energy demand and carbon emissions, there is a need to improve energy efficiency and pursue low-carbon development for industrial sectors. Therefore, it is worthwhile to pay close attention to the issue of reasonably reducing and controlling emissions in industrial sectors. The objective of this study is to perform a scientific and reasonable allocation model for allocating carbon emission quotas among industrial sectors and analyzing the different characteristic of emission reduction path for each industrial sector, thereby serving China's carbon trading market scheme and the achievement of carbon reduction targets.

\section{Materials and Methods}

Industrial Carbon Emissions Prediction

Model Based on an Environment Learning Curve

The ELC reflects the positive development of an enterprise or industry in terms of environmental protection and resource utilization due to accumulated experience and technological advances. In general, it is simplified as the regular change in energy and resource consumption, e.g., pollutant emissions per 10,000 yuan GDP with an increase in per capita GDP. Since the ELC has been proposed, it has been employed in many studies of environmental problems, such as carbon emissions [19], sulfur emissions [20] and other environmental impact issues [21].
Han [22] provides different meanings on the expression of the ELC model. Three one-factor models are proposed, comprising the log-linear model, B-curve type, and S-curve type. In this study, the log-linear form is employed in the industrial carbon emissions prediction model based on the ELC, where the model is calculated by using Eq. (1):

$$
Y(x)=Y_{1} x^{-b}
$$

...where $Y(x)$ isindustrial CEI, $x$ represents the per capita industrial added value, and $Y_{1}$ indicates the initial value of CEI when $x$ is set at a fixed value. $b$ is the learning coefficient of carbon emission reduction, which is larger when the increase of the environmental protection capacity is faster, and vice versa.

\section{Model for Allocating Carbon Emission Quotas in Industrial Sectors}

\section{IEMMA Model Construction}

1) Select $m$ industrial sectors and $n$ indicators, then $X_{i, j}(\mathrm{i}=1,2,3, \ldots, \mathrm{m} ; \mathrm{j}=1,2,3, \ldots \mathrm{n})$ is the value of the $\mathrm{jth}$ indicator in the ith industrial sector.

2) Standardize the indicator as $Y_{i, j}$. The specific methods are as follows:

Positive indicator:

$$
Y_{i, j}=\frac{X_{i, j}-\min X_{i, j}}{\max X_{i, j}-\min X_{i, j}}
$$

Negative indicator: $Y_{i, j}=\frac{\max X_{i, j}-X_{i, j}}{\max X_{i, j}-\min X_{i, j}}$

3) Under the jth indicator, calculate the proportion of the ith industrial sector relative to indicator $p_{i, j}$ :

$p_{i, j}=\frac{Y_{i, j}}{\sum_{i=1}^{m} Y_{i, j}},(i=1,2 \ldots m, j=1,2 \ldots n)$

4) Calculate the entropy of the jth indicator $e_{j}$ :

$$
e_{j}=-k \sum_{i=1}^{m} p_{i, j} \ln p_{i, j}
$$

...where $k>0, k=\frac{1}{\ln (m)}, e_{j} \geq 0$.

$$
\text { When } p_{i, j}=0, p_{i, j} \ln p_{i, j}=0
$$

5) Calculate the diversity factor of the jth indicator $E_{j}$ :

$$
E_{j}=1-e_{j}
$$

6) Calculate the entropy weight $\omega_{j}$.

Entropy weight represents the amount of effective information provided by the indicator in the final evaluation. The expected value is in the range of $[0,1]$. 


$$
\begin{gathered}
\omega_{j}=\frac{E_{j}}{\sum_{j=1}^{n} E_{j}}, 0 \leq \omega_{j} \leq 1, \sum_{j=1}^{n} \omega_{j}=1 \\
\quad(j=1,2 \ldots n)
\end{gathered}
$$

7) The direct weighting method is applied in the criterion layer to reflect the emphases of different allocation models. In the indicator layer $\omega_{i}$, the weights are determined by the entropy weight decision-making method based on the historical data. $\omega_{a}$ is the weighted value assigned to the ath criterion, and $a$ is the number of criterion layers, whose value is $1,2,3$, or 4 , respectively.

$$
W_{j}=\omega_{a} \times \omega_{j}
$$

8) Calculate the synthesis score for the indicator in each industrial sector $K_{i}$ :

$$
\begin{gathered}
\mathrm{K}=\mathrm{Y} \times W=\left[\begin{array}{ccc}
Y_{1,1} & \cdots & Y_{1, n} \\
\vdots & \ddots & \vdots \\
Y_{m, 1} & \cdots & Y_{m, n}
\end{array}\right] \times\left[\begin{array}{c}
W_{1} \\
\vdots \\
W_{n}
\end{array}\right]=\left[\begin{array}{c}
K_{1} \\
\vdots \\
K_{m}
\end{array}\right] \\
(i=1,2 \ldots m)
\end{gathered}
$$

9) Calculate the allocation factor in each industrial sector $T_{i}$ :

$$
T_{i}=\frac{1}{K_{i}}(i=1,2 \ldots m)
$$

10) Determine the allocation of the carbon emissions increments.

The energy-related $\mathrm{CO}_{2}$ emissions in all industrial sectors during 2014 are taken as the carbon emissions in the base year, and 2025 is treated as the target year for allocation. According to the predicted industrial carbon emissions in 2025 in China, the carbon emissions increments are allocated. The carbon emissions in 2014 (base year) are denoted as $C_{i, 2014}$. The allocation of carbon emissions increments in 2025 (target year) before adjustment is marked as $\Delta C_{i}^{0}$, which is the product of the allocation factor and carbon emissions in the base year.

$$
\Delta C_{i}^{0}=C_{i, 2014} \times T_{i}
$$

In accordance with the control of total emissions, the sum of carbon emissions in all industrial sectors is the sum of the total increment. Compared with the base year, the total increment in the target year is specified as $\Delta C$, so the adjustment coefficient $f$ is introduced.

$$
\begin{gathered}
\Delta C=\sum_{i=1}^{m} \Delta C_{i}=C_{2025}-C_{2014} \\
f=\frac{\Delta C}{\sum_{i}^{m} \Delta C_{i}^{0}}
\end{gathered}
$$

The carbon emissions increment in 2025 (target year) in all industrial sectors (after adjustment) is then denoted as $\Delta C_{i}$.

$$
\Delta C_{i}=\Delta C_{i}^{0} \times f \quad(i=1,2 \ldots m)
$$

(11) Determine the allocation of carbon emissions

The allocation of carbon emissions in 2025 (target year) in each industrial sector is the sum of the allocation of the carbon emissions increment and carbon emissions in 2014 (base year).

$$
\begin{aligned}
C_{i, 2025}= & C_{i, 2014}+\Delta C_{i}=C_{i, 2014}+ \\
& +C_{i, 2014} \times T_{i} \times f
\end{aligned}
$$

\section{Allocation Principle and Indicator System for Industrial Carbon Emission Quotas}

The principle of "common but differentiated responsibilities" has been used as the guiding principle for allocating carbon emissions permits. Given this principle, fairness, feasibility, and efficiency should all be considered when carbon emissions permits are allocated to industrial sectors. Thus, the carbon emissions in all industrial sectors are measured from the perspectives of the responsibility, capability, and potential for reducing emissions, as well as the industrial characteristics. Based on the representativeness of indicators and the availability of data, the index system comprising eight indicators is constructed for industrial carbon emission

Table 1. Allocation index system for $\mathrm{CO}_{2}$ emission quotas.

\begin{tabular}{|c|c|c|c|}
\hline Index Category & Indicator & Definition & Property \\
\hline \multirow{2}{*}{$\begin{array}{c}\text { Emission reduction } \\
\text { responsibility }\end{array}$} & Historical emissions & Carbon emissions in industrial sectors in base year & positive \\
\cline { 2 - 4 } & Carbon emission intensity & Carbon emissions/industrial production & positive \\
\hline \multirow{2}{*}{$\begin{array}{c}\text { Emission reduction } \\
\text { potential }\end{array}$} & Energy intensity & Energy consumption/industrial production & positive \\
\cline { 2 - 4 } & Energy mix & Coal consumption/ total energy consumption & positive \\
\cline { 2 - 4 } & Science and technology input & R\&D funds/main business cost & positive \\
\hline \multirow{2}{*}{$\begin{array}{c}\text { Emission reduction } \\
\text { capability }\end{array}$} & Per capita output & Per capita main business income & positive \\
\cline { 2 - 4 } & Profitability & Total profit/net assets & positive \\
\hline Industrial features & Openness & Industry export delivery value/industrial production value & positive \\
\hline
\end{tabular}


Table 2. Sector classification.

\begin{tabular}{|c|c|c|c|}
\hline Sector ID & Sector name & Sector ID & Sector name \\
\hline S1 & Mining and Washing of Coal & S21 & Manufacture of Chemical Fibers \\
\hline S2 & Extraction of Petroleum and Natural Gas & S22 & Manufacture of Rubber and Plastics Products \\
\hline S3 & Mining and Processing of Ferrous Metal Ores & S23 & Manufacture of Non-metallic Mineral Products \\
\hline S4 & Mining and Processing of Non-Ferrous Metal Ores & S24 & Smelting and Pressing of Ferrous Metals \\
\hline S5 & Mining and Processing of Non-metal Ores & S25 & Smelting and Pressing of Non-ferrous Metals \\
\hline S6 & Processing of Food from Agricultural Products & S26 & Manufacture of Metal Products \\
\hline S7 & Manufacture of Foods & S27 & Manufacture of General Purpose Machinery \\
\hline S8 & Manufacture of Liquor, Beverages and Refined Tea & S28 & Manufacture of Special Purpose Machinery \\
\hline S9 & Manufacture of Tobacco & S29 & Manufacture of Automobiles \\
\hline S10 & Manufacture of Textile & $\mathrm{S} 30$ & $\begin{array}{l}\text { Manufacture of Railway, Ship, Aerospace } \\
\text { and Other Transport Equipment }\end{array}$ \\
\hline S11 & $\begin{array}{l}\text { Manufacture of Textile, Wearing Apparel } \\
\text { and Accessories }\end{array}$ & $\mathrm{S} 31$ & $\begin{array}{l}\text { Manufacture of Electrical Machinery } \\
\text { and Apparatus }\end{array}$ \\
\hline $\mathrm{S} 12$ & $\begin{array}{c}\text { Manufacture of Leather, Fur, Feather and Related } \\
\text { Products and Footwear }\end{array}$ & $\mathrm{S} 32$ & $\begin{array}{l}\text { Manufacture of Computers, Communication } \\
\text { and Other Electronic Equipment }\end{array}$ \\
\hline S13 & $\begin{array}{l}\text { Processing of Timber, Manufacture of Wood, Bamboo, } \\
\text { Rattan, Palm and Straw Products }\end{array}$ & S33 & $\begin{array}{l}\text { Manufacture of Measuring Instruments } \\
\text { and Machinery }\end{array}$ \\
\hline S14 & Manufacture of Furniture & S34 & Other Manufacture \\
\hline S15 & Manufacture of Paper and Paper Products & S35 & Utilization of Waste Resources \\
\hline S16 & Printing and Reproduction of Recording Media & S36 & $\begin{array}{c}\text { Repair Service of Metal Products, Machinery } \\
\text { and Equipment }\end{array}$ \\
\hline S17 & $\begin{array}{l}\text { Manufacture of Articles for Culture, Education, Arts } \\
\text { and Crafts, Sport and Entertainment Activities }\end{array}$ & S37 & $\begin{array}{l}\text { Production and Supply of Electric Power and Heat } \\
\text { Power }\end{array}$ \\
\hline S18 & $\begin{array}{c}\text { Processing of Petroleum, Coking and Processing } \\
\text { of Nuclear Fuel }\end{array}$ & S38 & Production and Supply of Gas \\
\hline S19 & $\begin{array}{l}\text { Manufacture of Raw Chemical Materials and Chemical } \\
\text { Products }\end{array}$ & S39 & Production and Supply of Water \\
\hline S20 & Manufacture of Medicines & & \\
\hline
\end{tabular}

quota allocation. The allocation index system is presented in Table 1. If the property of an indicator is positive, the indicator positively corresponds to the contribution to $\mathrm{CO}_{2}$ emission reduction in an industrial sector.

\section{Data Specifications}

Given the availability and representativeness of data, 16 energy sources (comprising raw coal, coke, cleaned coal, other washed coal, coke oven gas, other coal gas, other coking products, liquefied petroleum gas, refinery gas, crude oil, gasoline, kerosene, diesel oil, fuel oil, other petroleum products, and natural gas) were selected to calculate the industrial carbon emissions in this study.

According to the National Industries Classification (GB/4754-2011) [23], the industrial sectors in China comprise 41 categories. The added values for all industrial sectors are not included in the national statistical system. Therefore, the output values for all industrial sectors are employed to replace the industrial added values, and the per capita output values are replaced by the per capita main business incomes for all industrial sectors. All of the data are from the China Statistical Yearbook [24], China Energy Statistical Yearbook [25], and China Industry Statistical Yearbook [26]. However, support activities for mining and mining of other ores lack adequate data, and given that the proportions of these two industrial sectors relative to the whole industry are very small, these two industries are ignored in this study. The sector classification is presented in Table 2 .

\section{Results and Discussion}

\section{Carbon Emissions Forecasting}

The ELC is constructed for industrial carbon emissions according to the per-capita industrial added value and CEI during 1991-2014. As the per-capita 
Table 3. Industrial carbon indicators for 2020 and 2025.

\begin{tabular}{|c|c|c|c|c|}
\hline Year & $\begin{array}{c}\text { Industrial carbon emission } \\
\text { intensity } \\
\text { (tons per 10,000 yuan) }\end{array}$ & $\begin{array}{c}\text { Industry carbon emissions } \\
(100 \text { million tons) }\end{array}$ & $\begin{array}{c}\text { Decline in carbon emission } \\
\text { intensity } \\
(2005 \text { as base year })\end{array}$ & $\begin{array}{c}\text { Decline in carbon emission } \\
\text { intensity } \\
\text { (2015 as base year) }\end{array}$ \\
\hline 2020 & 3.63 & 45.76 & $50.33 \%$ & $17.35 \%$ \\
\hline 2025 & 3.08 & 49.47 & $57.93 \%$ & $29.99 \%$ \\
\hline
\end{tabular}

industrial added value increases, the industrial CEI declines gradually. CEI and per capita industrial added value both exhibit exponential decay according to a power law. The simulated curve obtained for CEI and per-capita added value is, and determination coefficient, which is relatively significant.

The industrial carbon emissions and CEI in 2020 and 2025 are forecasted by estimating the average industrial output value per capita and the industrial added values in 2020 and 2025 through the ELC.

In May 2015 "Made in China 2025” was issued by the State Council and one of its main targets is that the annual average growth rates of the overall labor productivity in the manufacturing industry will be $7.5 \%$ and $6.5 \%$ during the " $13^{\text {th }}$ Five-year" and " $14^{\text {th }}$ Five-year" periods, respectively. Thus, we assume that the annual average growth rates of the average industrial output value per capita will be $7.5 \%$ and $6.5 \%$ during 2016-2020 and 2021-2025, respectively.

The total industrial added value increased by $5.9 \%$ in 2015. The added value of the industrial enterprises above the designated amount rose by $6.1 \%$ and $6 \%$ in 2015 and 2016, respectively, and the target in 2017 is in line with that in 2016. Furthermore, the industrial added value decreases each year, whose growth rate is slower than that of the industrial added value above the designated amount. In conclusion, we assume that growth rates of the industrial added value during the " $13^{\text {th }}$ Five-year" and " $14^{\text {th }}$ Five-year" periods will be $5.5 \%$ and $5 \%$, respectively.

The indicator of industrial output value per capita is substituted into the simulated ELC, and CEI is estimated for 2020 and 2025. Based on annual average growth rates of $5.5 \%$ and $5 \%$, the industrial added values in 2020 and 2025 are calculated accordingly. Then industrial carbon emissions in 2020 and 2025 are estimated according to projected CEI in 2020 and 2025, respectively. The final forecasts are presented in Table 3.

As shown in Table 3, compared with the industrial CEI in 2005 of 7.32 tons per 10,000 yuan, the industrial CEI in 2020 will decrease by $50.33 \%$. This meets the $40-45 \%$ CEI reduction target China promised at the Copenhagen
Accord in 2009 [27]. The total industrial carbon emissions account for about $70 \%$ of the carbon emissions in China. Thus, a greater decline in the industrial CEI will have a positive effect on achieving the target of CEI mitigation in China.

The industrial CEI reductions in 2020 and 2025 in Table 3 are far from the goals of $22 \%$ in 2020 and $40 \%$ in 2025 in the manufacturing industry according to "Made in China in 2025." By using the method in Data Specifications, the industrial carbon emissions and the carbon emissions in the manufacturing industry in 2014 were calculated, which were $4.09894 \times 10^{9}$ tons and $3.86120 \times 10^{9}$ tons, respectively. The carbon emissions in the manufacturing industry accounted for $94.2 \%$ of the industrial carbon emissions in China. Therefore, it will be difficult to meet the emission reduction target proposed in "Made in China in 2025" under the current development pattern.

\section{Carbon Emission Quota Allocation in Industrial Sectors}

\section{Scenario Setting}

The selected indicators are all positive, so the raw data are standardized by using Eq. (2). The entropy for each indicator is based on the proportion of the indicator. The entropy obtained for each indicator represents the difference in degree among the indicator data. If the difference in the indicator data is greater, more information is provided by the indicator and a larger weight is given. The entropy weight is calculated for each indicator based on the entropy of each indicator, as shown in Table 4.

The subjective weight determination is utilized in the criterion layer, which provides the weighted values $\omega_{a}$ as follows:

- Scenario 1: we focus on emission reduction responsibility, where $\omega_{1}=0.4$ and $\omega_{2}=\omega_{3}=\omega_{4}=0.2$.

- Scenario 2: we highlight emission reduction potential, where $\omega_{2}=0.4$, and $\omega_{1}=\omega_{3}=\omega_{4}=0.2$.

- Scenario 3: we focus on emission reduction capability, where $\omega_{3}=0.4$, and $\omega_{1}=\omega_{2}=\omega_{4}=0.2$.

Table 4. Entropy weight of each indicator.

\begin{tabular}{|l|c|c|c|c|c|c|c|c|}
\hline Variables & $\begin{array}{c}\text { Historical } \\
\text { emissions }\end{array}$ & $\begin{array}{c}\text { Carbon } \\
\text { emission intensity }\end{array}$ & $\begin{array}{c}\text { Energy } \\
\text { intensity }\end{array}$ & $\begin{array}{c}\text { Energy } \\
\text { mix }\end{array}$ & $\begin{array}{c}\text { Science and } \\
\text { technology input }\end{array}$ & $\begin{array}{c}\text { Per- capita } \\
\text { output }\end{array}$ & Profitability & Openness \\
\hline Entropy & 0.1289 & 0.1264 & 0.1249 & 0.1239 & 0.1241 & 0.1241 & 0.1230 & 0.1247 \\
\hline
\end{tabular}


Table 5. Weight of each variable under different scenarios.

\begin{tabular}{|l|c|c|c|c|c|c|c|c|}
\hline & $\begin{array}{c}\text { Historical } \\
\text { emissions }\end{array}$ & $\begin{array}{c}\text { Carbon } \\
\text { emission } \\
\text { intensity }\end{array}$ & $\begin{array}{c}\text { Energy } \\
\text { intensity }\end{array}$ & $\begin{array}{c}\text { Energy } \\
\text { mix }\end{array}$ & $\begin{array}{c}\text { Science } \\
\text { and technology } \\
\text { input }\end{array}$ & $\begin{array}{c}\text { Per capita } \\
\text { output }\end{array}$ & Profitability & Openness \\
\hline Scenario 1 & 0.0515 & 0.0505 & 0.0250 & 0.0248 & 0.0248 & 0.0248 & 0.0246 & 0.0249 \\
\hline Scenario 2 & 0.0258 & 0.0253 & 0.0500 & 0.0496 & 0.0496 & 0.0248 & 0.0246 & 0.0249 \\
\hline Scenario 3 & 0.0258 & 0.0253 & 0.0250 & 0.0248 & 0.0248 & 0.0496 & 0.0492 & 0.0249 \\
\hline Scenario 4 & 0.0258 & 0.0253 & 0.0250 & 0.0248 & 0.0248 & 0.0248 & 0.0246 & 0.0499 \\
\hline Scenario 5 & 0.0322 & 0.0316 & 0.0312 & 0.0310 & 0.0310 & 0.0310 & 0.0308 & 0.0312 \\
\hline
\end{tabular}

- Scenario 4: we highlight the differences among industrial sectors, where $\omega_{4}=0.4$, and $\omega_{1}=\omega_{2}=$ $\omega_{3}=0.2$.

- Scenario 5: this is the averaging weighting scheme, where $\omega_{1}=\omega_{2}=\omega_{3}=\omega_{4}=0.25$.

The total weight $W_{j}$ obtained by combining the subjective weight determinations with the objective weight determinations is calculated through Eq. (8), and the results are listed in Table 5.

\section{Results of Carbon Emission \\ Quota Allocation}

In terms of the indicator weights under different scenarios and the indicator values obtained for all industrial sectors after standardization, the synthesis score and allocation factor are solved by using Eqs (9) and (10), respectively. The synthesis score for carbon emissions reflects the responsibility for reducing emissions assigned to each industrial sector. The allocation factor represents the difference in the increases in carbon emission allocations. The allocation is smaller when the synthesis score is higher, which indicates that the shared responsibility for carbon emission mitigation is greater and the increase in carbon emissions is smaller, and vice versa.

The allocated factors, carbon emissions in all industrial sectors in 2014 (base year), and total controlled emissions in 2025 (target year) are substituted into Eqs (11) to (15), and the total carbon emission allocations among all industrial sectors in the target year under 5 scenarios are estimated.

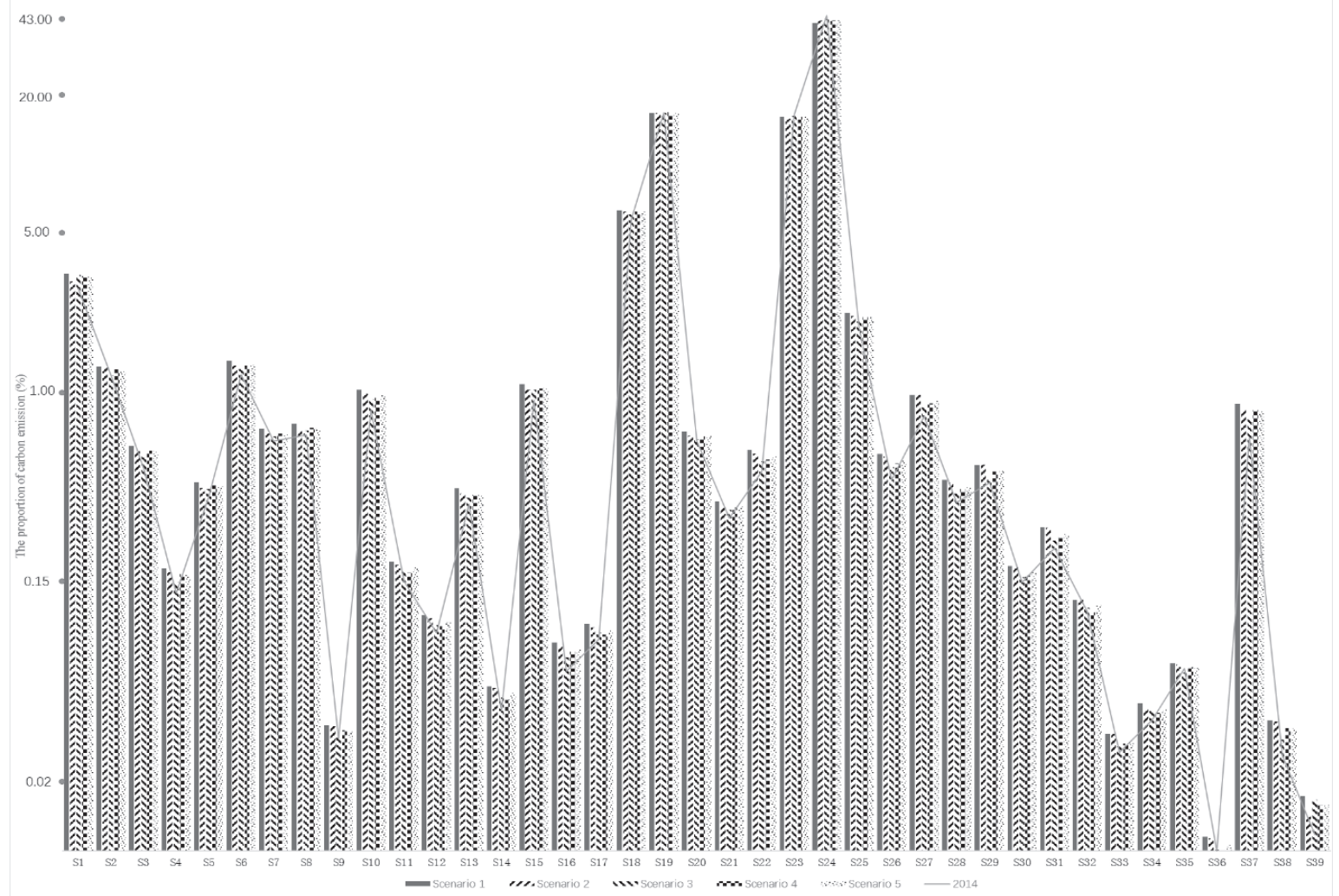

Fig. 1. Proportions of carbon emissions in the industrial sectors.

Note: S1-39 represent 39 sectors, as shown in Table 2 
According to the allocation results, the proportions of carbon emissions in all industrial sectors under different scenarios in 2025 are plotted in Fig. 1.

Fig. 1 indicates that the proportions of historical emissions and emission quotas under 5 scenarios in smelting and pressing of ferrous metals (S24) are close to $43 \%$. For three industrial sectors, the proportions are over $5 \%$, and there are 3 sectors where the proportions are more than $1 \%$. The proportions for the other sectors are all less than $1 \%$. In terms of the different scenarios, the proportions of historical emissions in 4 industrial sectors (i.e., S19, S23-25) are larger than those of emission quotas under 5 scenarios in 2025. The allocation proportions in 2025 are larger than those of the historical emissions in other industrial sectors. However, there are large differences in the historical emissions, thus, few industrial sectors reduce proportions and many industrial sectors increase proportions, so the differences between the emission quotas proportions and historical emission proportions in all industrial sectors are not obvious in 2025.

\section{Growth of Carbon Emissions}

Using 2014 as the base year, the growth rates are estimated for the carbon emissions under different scenarios in 2025. Based on the results, the rankings of the growth rates under different scenarios in 2025 and the proportions of historical emissions in all industrial sectors are plotted in Fig. 2.
As presented in Fig. 2, the bar chart indicates the rankings of the growth rate in carbon emissions of all industrial sectors under 5 scenarios, and the line chart shows the rankings of the historical emissions (the ranking is higher when the growth rate is smaller, while lower when the emissions are higher). There are large differences in the rankings for S2, 6-8, 18-19, 23, 24, where the rankings of the historical emissions are much lower than those of the growth rates. The rankings for historical emissions are all low for 8 industrial sectors, where the emissions are large and account for over $87 \%$ of the total industrial carbon emissions. By contrast, the growth rate rankings for $\mathrm{S} 4,11-12,14,16$, and 38-39 are higher than those of the historical emissions. In particular, there are dramatic differences between 2 evaluation indicators for S38 and S39. For these 2 industrial sectors, the historical emissions rank the third and second, respectively, whereas their growth rate rankings are in the range of 29-39. Carbon emission allowance is a type of resource and developmental right and the growth rates should be small in industrial sectors with high historical emissions, but large in industrial sectors with low historical emissions, which reflects the fairness of the carbon quota allocation system.

In terms of the growth rate of the same industrial sector under different scenarios, the growth rates of S1, 19, 23, and 24 are not maximal under Scenario 1, while the growth rates of the other 35 industrial sectors are all maximal under Scenario 1. This is because Scenario 1 focuses on the responsibility for reducing emissions

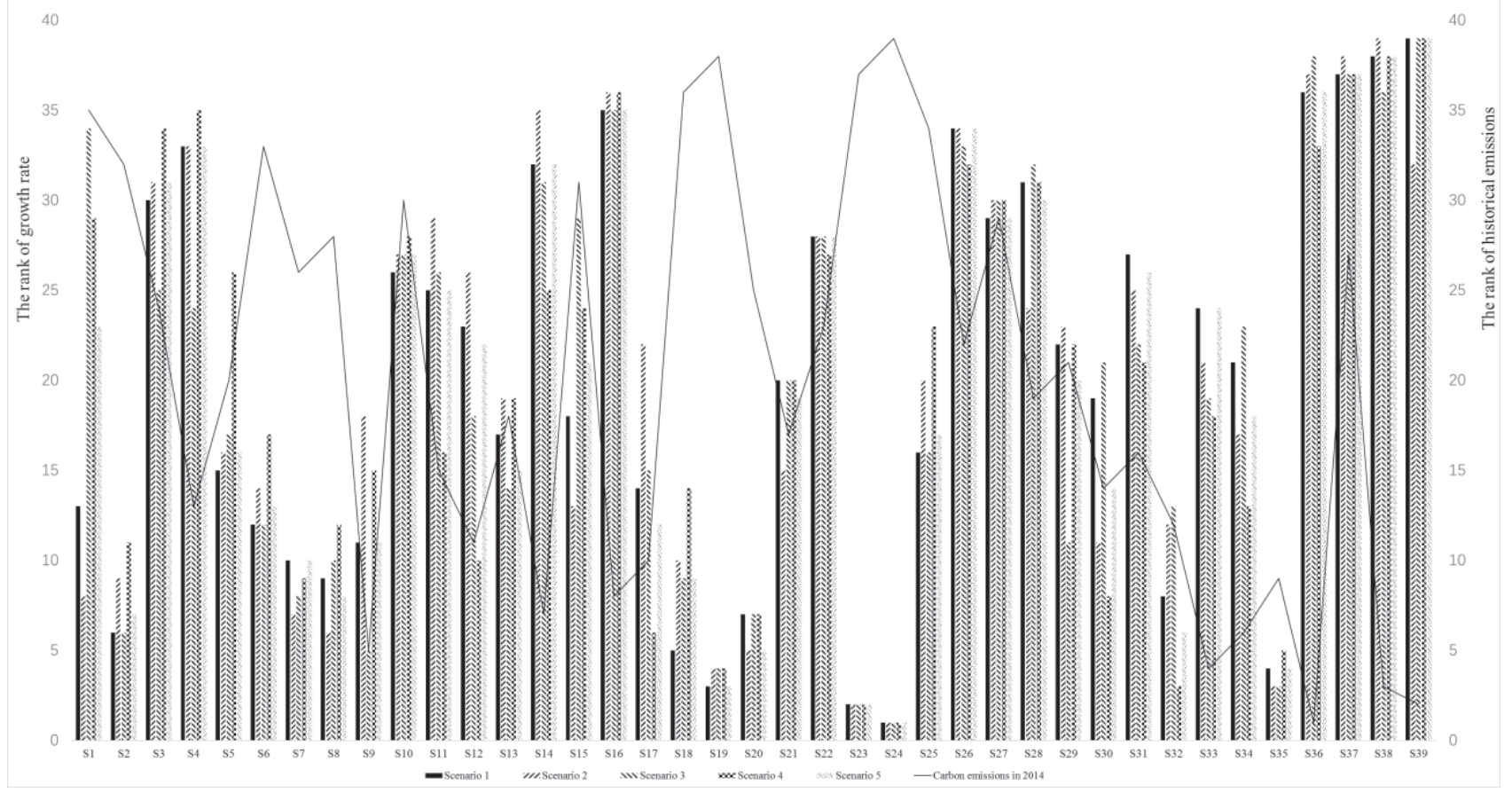

Fig. 2. Ranking of growth rate and historical emissions of industrial sectors in 2025.

Note: S1-39 represent 39 sectors, as shown in Table 2 
by considering the indicators of historical emissions and CEI. The carbon emissions in 4 industrial sectors - including smelting and pressing of ferrous metals (S24) - account for a substantial part of the industrial emissions, and they differ greatly from those in the other industries. Thus, these 4 industrial sectors shoulder greater responsibility for emission mitigation, and they will have lower carbon quotas. Their carbon emission quotas will be allocated to the industrial sectors with lower carbon emissions. Therefore, under Scenario 1, the other industrial sectors with low emissions have larger growth rates in their carbon emissions, which are larger than those under the other scenarios.

Under Scenario 1, the growth rate of S24 is only $12.38 \%$. For all industrial sectors, the growth rate in the carbon emissions is $21 \%$. In the other industrial sectors (except for S23), the growth rates are all higher than $21 \%$ and mostly in the range of $30-50 \%$. By contrast, the growth rate of $\mathrm{S} 24$ is very low under Scenario 1, thereby resulting in excessively large growth rates in other industrial sectors. If the carbon emission quotas are allocated according to Scenario 1, then the quotas for S24 will be reduced dramatically and it will be difficult to sustain production. Moreover, the excessively large growth rates of other industrial sectors will not help to reduce carbon emissions and they may even accelerate the growth of carbon emissions. Thus, we suggest ignoring the results obtained under Scenario 1.

Under Scenario 2, the growth rates of nine industrial sectors (including S1, 15, 19-21, 23, 24, 35, and 39) are minimal. Scenario 2 focuses on the potential reduction of emissions, where the measurement indicators are energy intensity, energy mix, and science and technology input. Thus, the potential reductions of emissions in these 9 industrial sectors are greater. If measures are taken to reduce emissions, the potential to reduce emissions can be fully implemented. For example, production can be cleaner by enhancing energy utilization efficiency, upgrading energy mix to a lower proportion of fossil energy, and improving the production technology by increasing science and technology inputs.

Under Scenario 3, which focuses on the capability of reducing emissions, the growth rates in carbon emissions of 21 industrial sectors (including S2-11, 13, 16, 18, 22, 25-29, and 37-38) are minimal, which indicates that the capability of emission abatement is higher in these 21 industrial sectors. We characterize the capability of reducing emissions based on per capita output value and profitability. Thus, the 21 industrial sectors including extraction of petroleum and natural gas (S2) have greater profitability or higher per capita output value. These 21 industrial sectors should exploit their higher per capita output and greater profitability to increase investment in the development of technology for reducing emissions. In terms of the principle that a higher capability implies greater responsibility, these 21 industrial sectors should have greater responsibility for emission mitigation.
Under Scenario 4, the growth rates of carbon emissions in 9 industrial sectors (including S12, 14, 17, 30-34, and 36) are minimal. Scenario 4 focuses on industrial features characterized by openness of industrial sectors, and it indicates that these 9 industrial sectors are more open in foreign trade. Thus, these 9 industrial sectors should exploit their higher industrial openness and strengthen the introduction of advanced technology and high-level talent via trade abroad, thereby producing low-carbon products. Under Scenario 5 based on the averaging weight scheme, the growth rates of 11 industrial sectors (including S6, 7, 10, 13, 20-22, 25, 27, 28, and 33) are maximal. Therefore, various factors should be considered to formulate the emission reduction scheme.

\section{Conclusions}

In this study, we constructed an allocation scheme for carbon emission quotas by using the IEMMA model, which promotes collaborative equity and efficiency in the process of allocation. Multiple factors - including emission reduction responsibility, emission reduction potential, emission reduction capability, industrial features, and the average weighting allocation - are taken into account. Five allocation scenarios are investigated for industrial carbon emission quotas allocated to 39 sub-industries in 2025. The results suggest that the industrial carbon quota allocations under different scenarios follow various patterns, and there are large differences in the allocation results for each industrial sector. The proportion of carbon emission quotas allocated to each industrial sector is basically the same as that of historical emissions. Therefore, for industrial sectors with higher historical emissions, the growth rate of carbon emissions is obviously smaller than that in industrial sectors with lower historical emissions. Compared with other four Scenarios, Scenario 5 is the average weighting allocation scheme, which comprehensively measures 4 characteristics in all industrial sectors and also considers fairness, efficiency, and feasibility.

With the rise of the shale oil industry, President Trump declared America's withdrawal from the Paris Accord, aiming to promote energy independence and revive the petrochemical and coal industries in the U.S. Perhaps Trump's decision will influence energy-related industries in China; carbon quotas of these industries may be lowered accordingly, such as mining and washing of coal and extraction of petroleum and natural gas. In conclusion, China should set a specific two-level carbon-trading threshold for industrial sectors and enterprises based on the development situation, the stage of construction of the trading system, the scheme for planning the scale of transactions, and other actual conditions. Moreover, a scientific initial allocation scheme should be formulated for industrial carbon emission permits in order to exploit the potential for reducing emissions in the key industrial sectors and enterprises that consume large amounts of energy. 


\section{Acknowledgements}

This work was supported by the National Natural Science Foundation of China (grant No. 71573254) and Fundamental Research Funds for the Central Universities (grant No. 2015XKMS091). The authors also would like to thank the anonymous reviewers for their helpful suggestions on an earlier draft of this study.

\section{References}

1. GUMULA S., PYTEL K., PIASKOWSKA-SILARSKA M. Polemical Remarks to the Claim that Carbon Dioxide Strengthens the Greenhouse Effect in the Atmosphere. Pol. J. Environ. Stud. 23 (6), 2321, 2014.

2. MFA. U.S.-China Joint Announcement on Climate Change. Ministy of Foreign Affairs of People's Republic of China, Beijing, 2015.

3. CHANG X., LI Y., ZHAO Y., WU J. Effects of carbon permits allocation methods on remanufacturing production decisions. J. Clean. Prod. 152, 281, 2017.

4. RINGIUS L, TORVANGER A, UNDERDAL A. Burden Sharing and Fairness Principles in International Climate Policy. Int. Environ. Agreem-P. 2 (1), 1, 2002.

5. ZHANG Y.J., WANG A.D., DA Y.B. Regional allocation of carbon emission quotas in China: Evidence from the Shapley value method. Energ. Policy. 74 (C), 454, 2014.

6. KANDER A., JIBORN M. A new way of allocating responsibility for carbon emissions: Swedish consumption based emissions adjusted for NEGA-emissions. Soc. Sci. 2014.

7. HAN R., TANG B.J., FAN J.L., LIU L.C., WEI Y.M. Integrated weighting approach to carbon emission quotas: an application case of Beijing-Tianjin-Hebei region. J. Clean. Prod. 131, 448, 2016.

8. ZHANG Y.J., HAO J.F. Carbon emission quota allocation among China's industrial sectors based on the equity and efficiency principles. Ann. Oper. Res. 255 (1-2), 117, 2017.

9. FILAR J.A., GAERTNER P.S. A sectoral allocation of world $\mathrm{CO}_{2}$, emission reductions. Math. Comput.Simulat. 43 (3-6), 269, 1997.

10. YU S., WEI Y.M., WANG K. Provincial allocation of carbon emission reduction targets in China: An approach based on improved fuzzy cluster and Shapley value decomposition. Energ. Policy. 66 (7), 630, 2014.

11. CHIU Y.H., LIN J.C., HSU C.C., JIA W.L. Carbon emission allowances of efficiency analysis: Application of super SBM ZSG-DEA model. Pol. J. Environ. Stud. 22 (3), 653, 2013.

12. SUN J., WU J., LIANG L., ZHONG R.Y., HUANG G.Q. Allocation of emission permits using DEA: centralized and individual points of view. Int. J. Prod. Res. 52 (2), 419, 2014.
13. LIU Z., GENG Y., LINDER S, GUAN D. Uncovering China's greenhouse gas emission from sectoral and sectoral perspectives. Energy, 45 (1), 1059, 2012.

14. ZHANG Y.J., DA Y.B. Decomposing the changes of energyrelated carbon emissions in China: evidence from the PDA approach. Nat. Hazards. 69 (1), 1109, 2013.

15. YI W.J., ZOU L.L., GUO J., WANG K., WEI Y.M. How can China reach its $\mathrm{CO}_{2}$, intensity reduction targets by 2020 ? A sectoral allocation based on equity and development. Energ. Policy. 39 (5), $2407,2011$.

16. ZHOU P., ZHANG L., ZHOU D.Q., XIA W.J. Modeling economic performance of interprovincial $\mathrm{CO}_{2}$, emission reduction quota trading in China. Appl. Energy. 112 (16), 1518, 2013.

17. YU S., WEI Y.M., FAN J., ZHANG X., WANG K. Exploring the sectoral characteristics of inter-provincial $\mathrm{CO}_{2}$, emissions in China: An improved fuzzy clustering analysis based on particle swarm optimization. Appl. Energy. 92 (4), 552, 2012.

18. WU H., DU S., LIANG L., ZHOU Y. A DEA-based approach for fair reduction and reallocation of emission permits. Math. Comput. Model. 58 (5-6), 1095, 2013.

19. BROEK M.V.D., HOEFNAGELS R., RUBIN E., RUBIN E., FAAIJ A. Effects of technological learning on future cost and performance of power plants with $\mathrm{CO}_{2}$, capture. Prog. Energ. Combust. 35 (6), 457, 2009.

20. KUNNAS J., MYLLYNTAUS T. Anxiety and technological change - Explaining the inverted U-curve of sulphur dioxide emissions in late $20^{\text {th }}$ century Finland. Ecol. Econ. 69 (7), 1587, 2010.

21. HAN Y.F. Research on the Potential of Resource Saving and Emission Reducing of Papermaking Industry in China: Based on Environment Learning Curve. Adv. Mat. Res. 361-363, 1013, 2012.

22. HAN Y.F. Analysis of environment learning curve and the inter-province emission reducing potential in china. Shaanxi Normal University, 2008.

23. China's National Bureau of Statistics (CNBS). Industrial classification for national economic activities (GB/T 47542011); China Statistical Press: Beijing, 2011.

24. China's National Bureau of Statistics (CNBS). China Statistic Yearbook; China Statistical Press: Beijing, 2015.

25. China's National Bureau of Statistics (CNBS). China Energy Statistic Yearbook; China Statistical Press: Beijing, 2015.

26. China's National Bureau of Statistics (CNBS). China Industry Statistic Yearbook; China Statistical Press: Beijing, 2015.

27. DONG F., YU B.L., HADACHIN T., Dai Y.J., WANG Y., ZHANG S.N., LONG R.Y. Drivers of carbon emission intensity change in China. Resour. Conserv. Recycl. 129, 187, 2018. 
